\title{
Heavy metal pollution study of Onyi river in Obajana Community of Kogi State, Nigeria
}

\author{
Inyinbor A. $\mathrm{A}^{1}$, Adekola F. $\mathrm{A}^{2}$, Abdul Raheem A. M. $\mathrm{O}^{3}$. \\ ${ }^{1}$ Department of Chemistry, Landmark University, P.M.B 1001, Omu Aran, Nigeria. \\ ${ }^{2,3}$ Departments of Chemistry, University of Ilorin, P.M.B 1515, Ilorin, Nigeria.
}

\begin{abstract}
Abtract: Concentrations of $\mathrm{Pb}, \mathrm{Cu}, \mathrm{Zn}$ and $\mathrm{Mn}$ in aqueous effluents of a mega cement factory in Obajana, Kogi state of Nigeria have been studied. Onyi river in which these effluents are discharged was studied for these metals to ascertain its water quality status. Sediment samples were collected at various points along the river channel and they were subjected to chemical speciation following the Tessier sequential extraction procedure. The effluents concentrations range between $0.0506 \mathrm{mg} / \mathrm{L}$ and $4.2455 \mathrm{mg} / \mathrm{L}$ and concentrations of all the metals were found to be below the FEPA permissible limit for effluents discharged into the river. The concentrations of these metals in water were however, found to be higher than those of WHO standard for drinking water in certain location due to other anthropogenic activities. Concentration range for $\mathrm{Pb}, \mathrm{Cu}, \mathrm{Zn}$ and $\mathrm{Mn}$ were between 0.075 and $0.98 \mathrm{mg} / \mathrm{L}, 0.02$ and $4.24 \mathrm{mg} / \mathrm{L}, 0.05$ and $0.31 \mathrm{mg} / \mathrm{L}$ and 0.03 and $0.11 \mathrm{mg} / \mathrm{L}$ respectively. These metals were found to associate majorly with the non residual fractions.
\end{abstract}

Key words: Effluent, chemical speciation, heavy metals, Obajana-Nigeria, Onyi river, sediment,

\section{Introduction}

The importance of the environment to human is enormous. The hydrosphere, a component of the environment that constitute all water found on earth (river water, ocean, lakes e.t.c) has a great importance that cannot be over emphasized. River water plays an important role in the supply of fresh water to the public, it is also used for laundry, recreation, and supply of cooling for some industries. However, others consider river a convenient means of cleaning and carrying wastes such as urban, domestic or industrial effluents away from their point of discharge. The degradation of surface water due to the introduction of industrial effluents is now a serious concern to environmentalists [1].

Heavy metals constitutes a major category of pollutants in river because in large enough doses it can prove lethal to organisms including humans. These metals can be released into the river system by both natural and anthropogenic sources and during the course of their transportation can be distributed in water bodies, suspended sediment and bed sediment. Heavy metals occur in an unsual or abnormal concentration in river system as a result of pollution from minning process and other industrial activities [2,3]. These metals can be transported by particulate matters to the sediment which serves as the sink for these pollutants but do not permanently fix them because they can be released back to column water once there is a change in physicochemical conditions [4].

Chemical speciation is the distribution of individual chemical element among different species or groups which together comprise its total concentration in a given sample [5]. Trace metals may exists in different forms in the sediment and their concentration and forms of existence can play an important role in detecting sources, extent of pollution and distribution mechanisms in aquatic environment [6]. Information about the physico-chemical forms of elements is required for proper understanding of their mobility, pathway and bioavailability [7].

Availability of quality water for the maintanance of normal biological functions is on the decline, the agenda 21 of united nation in 1993 had it listed among other things that there should be protection of aquatic environment and associated resources. Goal 7, target 10, indicator 30 of the millenium development goals is an intention to halve the proportion of people without sustainable access to safe drinking water by 2015 . As a matter of fact, water problem has been identified as one of the major problems facing the modern world [8].

In Obajana community of Kogi state, Nigeria, the people in this community solely ( apart from tanker water supply by Dangote cement company which is irregular) depend on river onyi for all ther activities, including drinking, also a lot of fishing activities are carried out in this river especially in the dam and therefore the quality of this river must be ascertained. 


\section{Study Area}

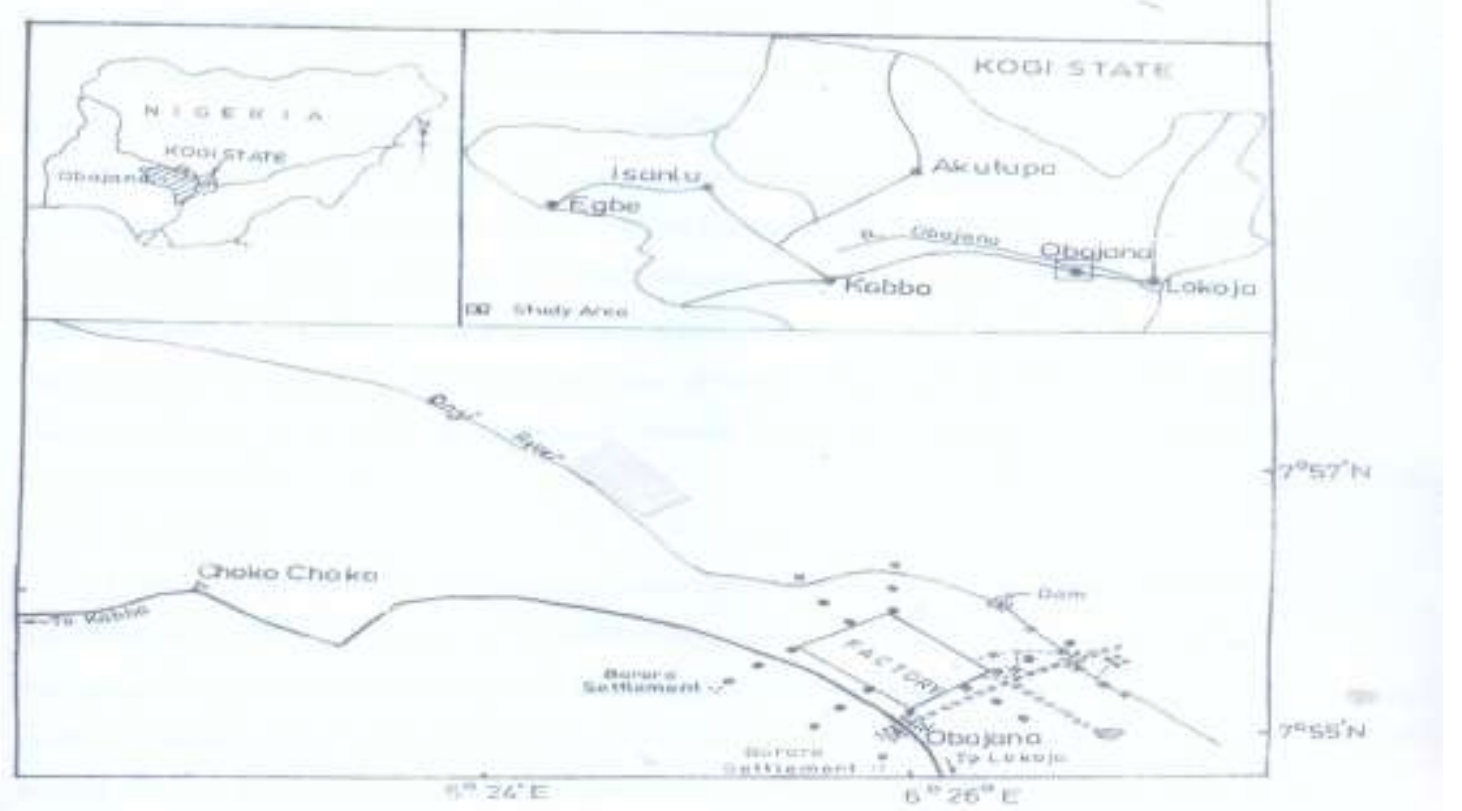

\section{Experimental}

Two effluents $\left(\mathrm{WE}_{\mathrm{w}}\right.$ and $\left.\mathrm{WE}_{\mathrm{N}}\right)$ discharged by a cement factory in Obajana, Kogi state, Nigeria were collected. River waters were collected at six different locations along Onyi river, respective sediment at each point was also collected. Location 1(POD) is the point of effluent discharge into the river, locations 2, 3 and 4 (BDD, 500MDS and 600MDS) are $100 \mathrm{~m}, 500 \mathrm{~m}$ and $600 \mathrm{~m}$ downstream point of effluent discharge respectively while locations 5 and 6 (500MUS and 1KMUS) are 500m distance and $1 \mathrm{~km}$ distance upstream point of effluent discharge . The choice of sample collection especially downstream was based on accessibility and other pollution such as domestic discharge into the river.

Effluents and water samples were collected in prepared sample bottles and $1 \mathrm{~cm}^{3} \mathrm{HNO}_{3}$ was added to keep the metals in solution. The river sediments were collected in polyethylene bag and later air dried in the laboratory.

The water and effluent samples were digested using $\mathrm{HClO}_{4}$ and $\mathrm{HCl}$ following the standard methods [9] and the sediments were subjected to chemical speciation following the Tessier's 5 steps sequential extraction procedure [10]. This was then followed by elemental analysis using a thermo S4 atomic absorption spectrophotometer. The instrument was operated as per the instrument's manual.

\section{Results And Discussions}

TABLE I: Total Concentration (mg/L) of $\mathrm{Pb}, \mathrm{Cu}, \mathrm{Zn}, \mathrm{Mn}$ and $\mathrm{Fe}$ in Effluent and their Federal Environmental Protection Agency (FEPA) Maximum Permissible Limit for Effluents discharge into the River

\begin{tabular}{|l|l|l|l|l|}
\hline Samples & $\mathbf{P b}$ & $\mathbf{C u}$ & $\mathbf{Z n}$ & $\mathbf{M n}$ \\
\hline $\mathrm{WE}_{\mathrm{W}}$ & 0.0725 & 0.0733 & 0.1038 & 4.2455 \\
\hline $\mathrm{WE}_{\mathrm{N}}$ & $<0.001$ & 0.0506 & 0.1006 & 0.2010 \\
\hline FEPA [11] & 1.0 & 1.0 & 1.0 & - \\
\hline
\end{tabular}

Table I shows the total concentration in $\mathrm{mg} / \mathrm{L}$ of $\mathrm{Pb}, \mathrm{Cu}, \mathrm{Zn}$ and $\mathrm{Mn}$ in the effluents discharged by the cement factory. The two effluents i.e west effluent designated with $\mathrm{WE}_{\mathrm{w}}$ and north effluent designated with $\mathrm{WE}_{\mathrm{N}}$ were observed to be distinct in there visual appearances. $\mathrm{WE}_{\mathrm{w}}$ was brown and foaming while $\mathrm{WE}_{\mathrm{N}}$ was clear at the time of collection. $\mathrm{Pb}, \mathrm{Cu}$ and $\mathrm{Mn}$ were found to be higher in concentration in $\mathrm{WE}_{\mathrm{w}}$ than in $\mathrm{WE}_{\mathrm{N}}$ while the concentrationsof $\mathrm{Zn}$ was practically the same. All the observed metals were lower than the permissible limit of FEPA effluent discharge into the river. 
Heavy metal pollution study of Onyi river in Obajana Community of Kogi State, Nigeria

TABLE II: Total Concentration (mg / L) of $\mathrm{Pb}, \mathrm{Cu}, \mathrm{Zn}$ and $\mathrm{Mn}$ in River Water and their Maximum Permissible Level for Drinking Water.

\begin{tabular}{|l|l|l|l|l|}
\hline Samples & Pb & $\mathbf{C u}$ & $\mathbf{Z n}$ & $\mathbf{M n}$ \\
\hline POD & 0.05 & 0.02 & 0.06 & 0.05 \\
\hline BDD & 0.95 & 4.24 & 0.08 & 0.10 \\
\hline 500MDS & 0.60 & 4.16 & 0.07 & 0.11 \\
\hline 600MDS & 0.98 & 3.22 & 0.31 & 0.06 \\
\hline 500MUS & 0.15 & 3.53 & 0.05 & 0.04 \\
\hline 1 KMUS & 0.07 & 0.81 & 0.08 & 0.03 \\
\hline WHO [12] & 0.05 & 1.00 & 5.00 & 0.10 \\
\hline
\end{tabular}

Table II shows the total concentration $(\mathrm{mg} / \mathrm{L})$ of $\mathrm{Pb}, \mathrm{Cu}, \mathrm{Zn}$ and $\mathrm{Mn}$ in the river water. At the Point of effluent Discharge into the river (POD) the concentration of all the metals dropped considerably and this could be attributed to the dilution of the effluents with river water (Table II). Down the stream just Before Domestic Discharge into the river (BDD) the concentration of all the metals increased when compared with their concentration at POD (Table II), this could be because BDD is very close to the bridge through which vehicles ply and the high concentration of $\mathrm{Pb}$ and $\mathrm{Zn}$ among other metals could results from combustion of fossil fuel and tire wares [13]. Farmers also wash their farm tools, farm produce and bath near this point, these activities could introduce agrochemicals into the river which could be a source of $\mathrm{Cu}$ [4]. $\mathrm{Pb}$ concentration was found to be highest at 600MDS. The concentration of $\mathrm{Cu}$ decreases from BDD through 500MDS to 600MDS as a result of dilution as the river flows down. Mn concentration is highest at 500MDS when compared with other river samples which could be as a result of erosion of $\mathrm{Mn}$ from the soil into the river water because from the investigation carried out on soil around that environment, the soil is rich in Mn [14]. 500m upstream (500MUS) to $1 \mathrm{~km}$ upstream (1KMUS) from POD, the concentration of all the metals decreased except for $\mathrm{Zn}$ in which concentration at 1KMUS almost doubled that at 500MUS and this can be attributed to high fishing activities in the dam where 1KMUS sample was collected and also erosion of dredged soil into the dam can as well contribute to the high concentration of Fe in the dam. Mn was also found to be lower except at 500MDS where it was a bit higher. $\mathrm{Pb}$ was found to be higher than $\mathrm{WHO}$ standard at all point except at POD. $\mathrm{Cu}$ was also found to be higher at all points except at POD and 1KMUS while $\mathrm{Zn}$ was found to be higher at all points of sample collection.

\subsection{Chemical Speciation of river sediment}

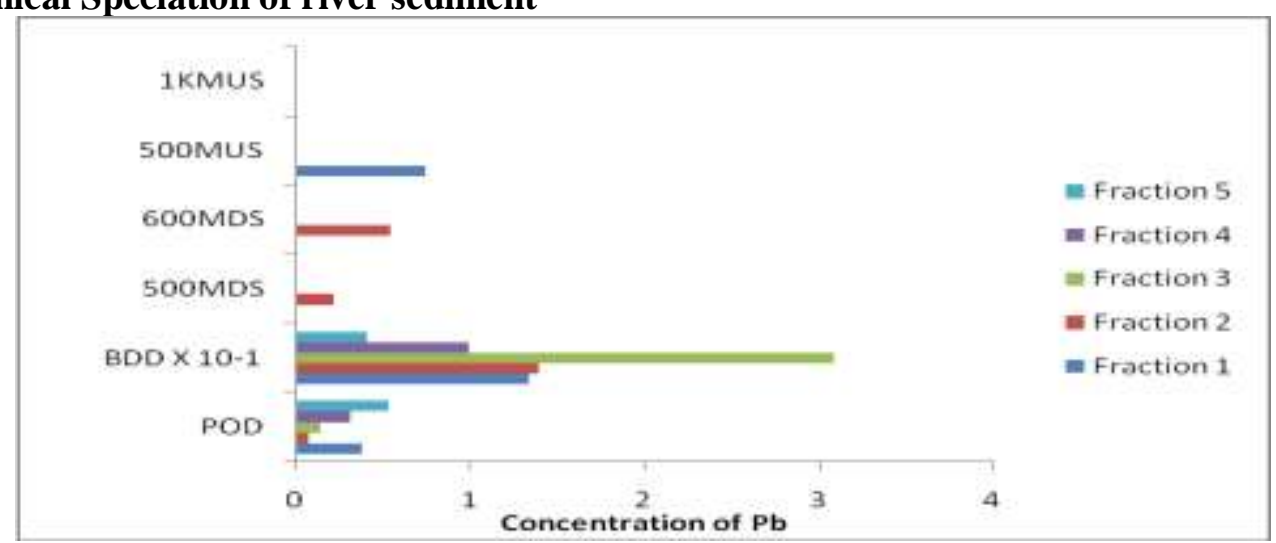

Figure 1: $\mathrm{Pb}$ concentration $(\mathrm{mg} / \mathrm{kg})$ in various fractions of sediment samples

The concentration of $\mathrm{Pb}$ for most of the samples was found to be below the detection limit of the atomic absorption spectrophotometer used for this analysis $(0.001)$. However, $\mathrm{Pb}$ has its highest concentration bounded to Fe-Mn fraction (fraction3) of the sample collected at location 2 (BDD), the concentration of $\mathrm{Pb}$ at $\mathrm{BDD}$ was found to be higher than all other samples investigated. This point is the closest to the road and also close to the company guest house hence particulate matters from combustion engine could be responsible for the high concentration of $\mathrm{Pb}$ at this point [13]. 


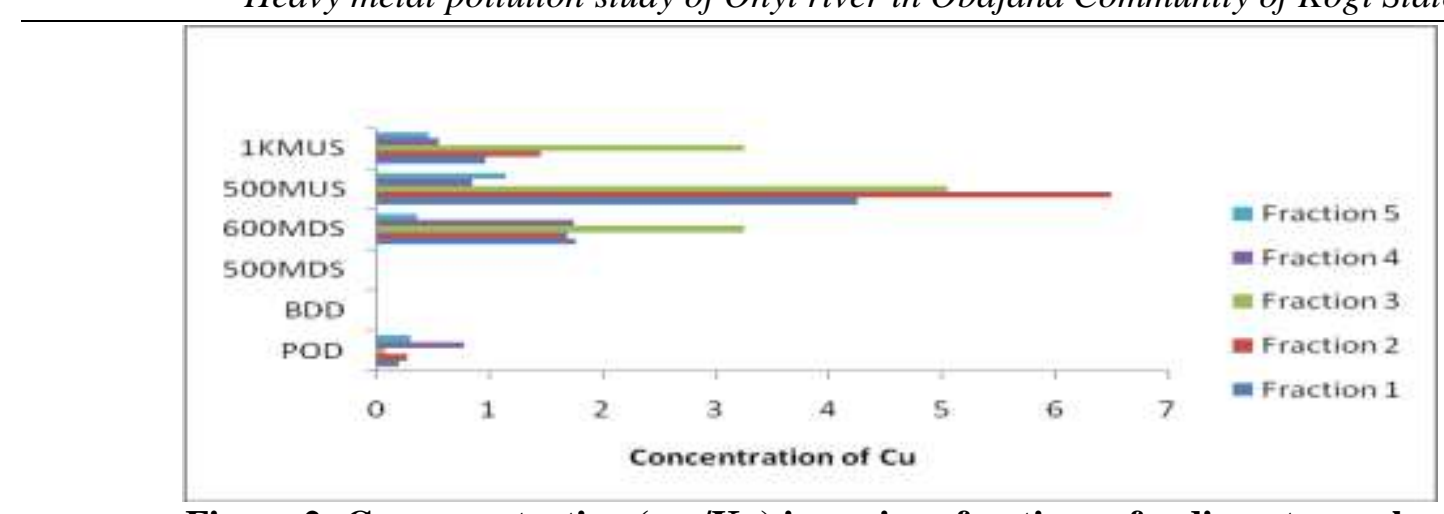

Figure 2: $\mathrm{Cu}$ concentration $(\mathrm{mg} / \mathrm{Kg})$ in various fractions of sediment samples

$\mathrm{Cu}$ concentration was found to be low at the point of effluent discharge (POD). Upstream the point of effluent discharge (500MUS and 1KMUS) and the farthest downstream (600MDS) was found to have higher $\mathrm{Cu}$ concentration than POD. The highest concentration of $\mathrm{Cu}$ was found to be bounded to carbonate of 500MUS sample (Fig 2). 500MUS is a location under the conveyor belt that carries raw material into the factory and some part of these raw materials constantly fall into the river. Cement raw material could be the source of various heavy metals in cement manufacturing processes [15].

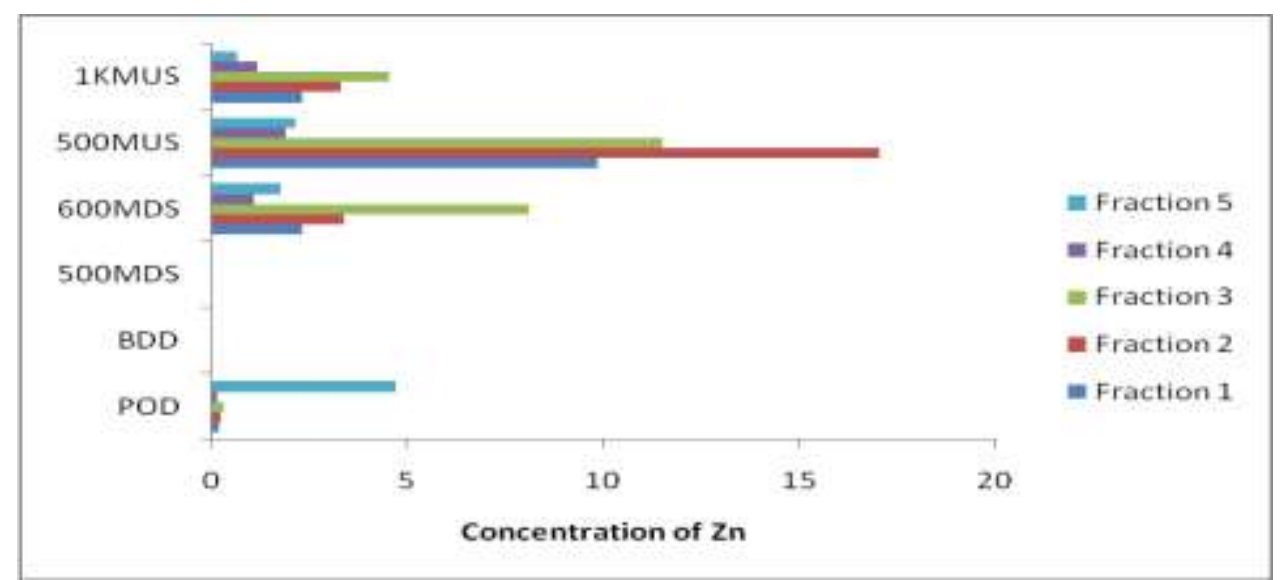

Figure 3: $\mathrm{Zn}$ concentration $(\mathrm{mg} / \mathrm{Kg})$ in various fractions of sediment samples

The $\mathrm{Zn}$ of POD was found to greatly associate with the residual fraction (fraction 5), concentration of $\mathrm{Zn}$ was found to be higher at 500MUS, 1KMUS and 600MDS than at POD. Zn has its highest concentration bound to carbonate of the sample collected at location 5 (500MUS) (Fig 3).

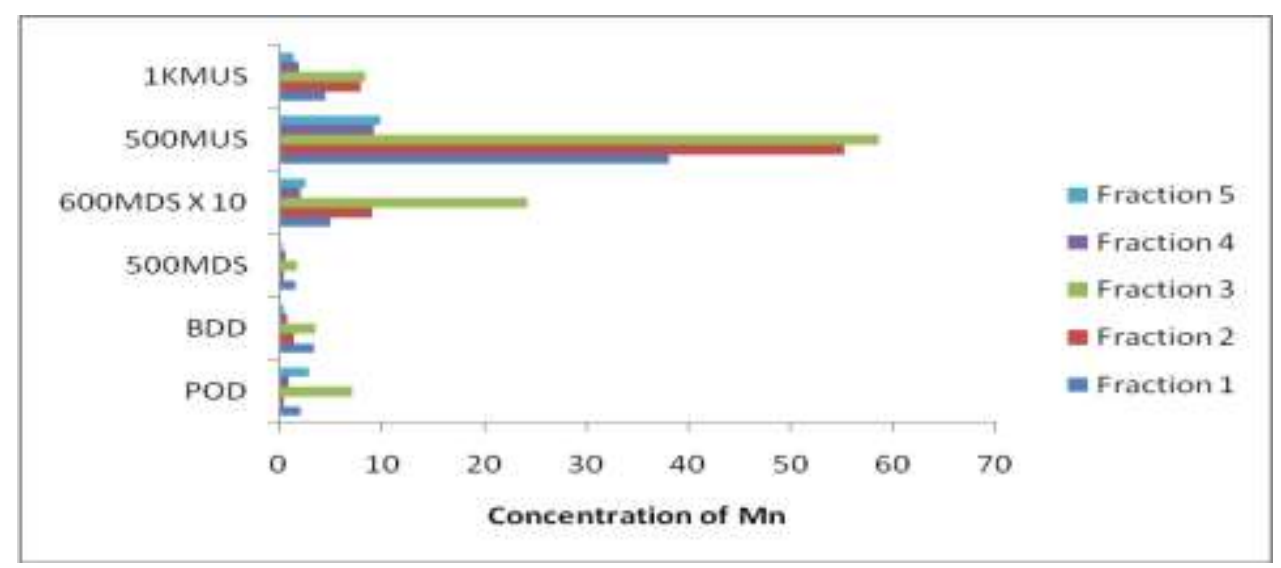

Figure 4: Mn concentration $(\mathrm{mg} / \mathrm{Kg})$ in various fractions of sediment samples

All the sample was found to have varying Mn concentration, the soil of the community as investigated was found to be rich in Mn. Higher concentration was observed for locations 500MUS, 1KMUS AND 600MDS 
Heavy metal pollution study of Onyi river in Obajana Community of Kogi State, Nigeria than all other locations. In all the samples investigated, Mn was found to associate with Fe-Mn fraction (Fraction 3). Associations of Mn with Fe-Mn fraction have been reported [16].

\subsubsection{Comparing The Percentage Mobility, \% Residual And \% Non Residual Fractions Of Pod,} 600mds, 500mus And 1kmus.

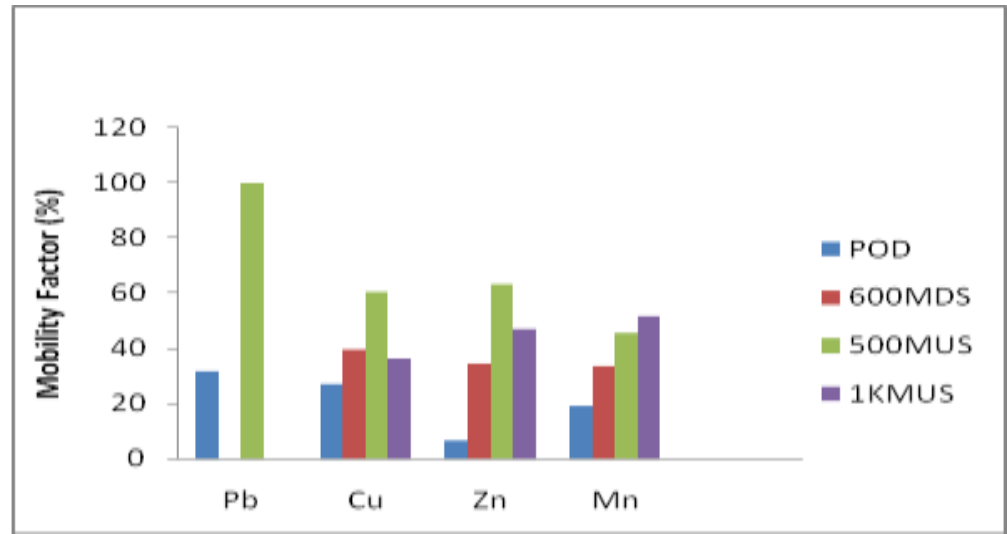

Figure 5: Comparing the percentage mobility of $\mathrm{Pb}, \mathrm{Cu}, \mathrm{Zn}$ and $\mathrm{Mn}$ in samples collected at POD, 600MDS, 500MUS and 1KMUS.

Pollution is usually expressed in the accumulation of toxicants such as heavy metals, the major concern is the bioavailability and mobility of such toxicant to living organism which basically determines its toxicity. Bioavailability refers to the amount of the metal that is available to organisms, including humans, for uptake from the sediment. Mobility factor was highest for $\mathrm{Pb}, \mathrm{Cu}$ and $\mathrm{Zn}$ in 500MUS while mobility was highest for Mn at 1KMUS.

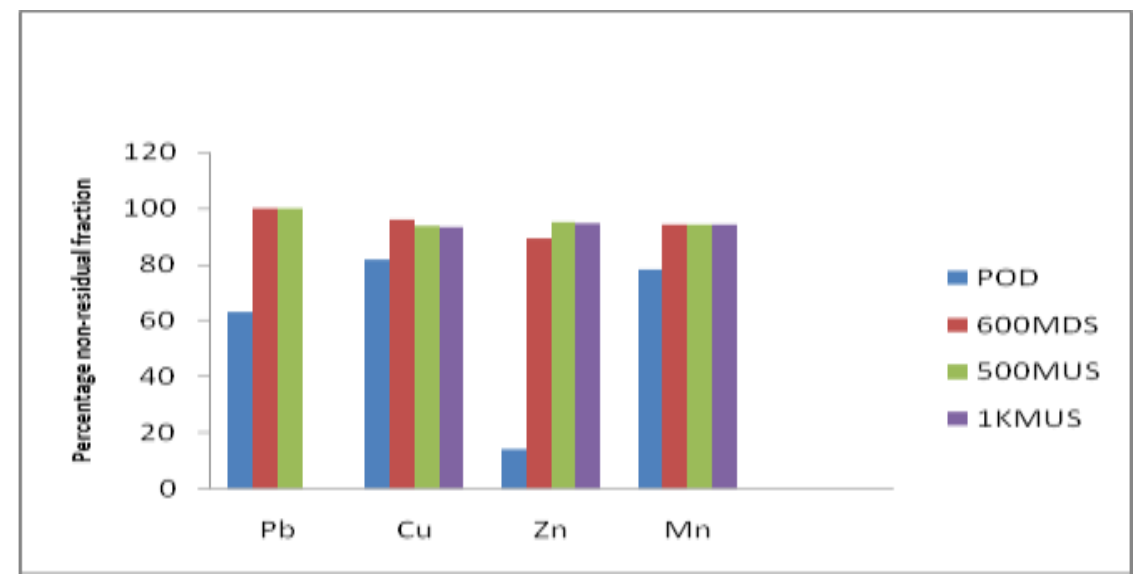

Figure 6: Comparing the percentage residual fraction of $\mathrm{Pb}, \mathrm{Cu}, \mathrm{Zn}$ and $\mathrm{Mn}$ in sample collected at POD, 600MDS, 500MUS and 1KMUS.

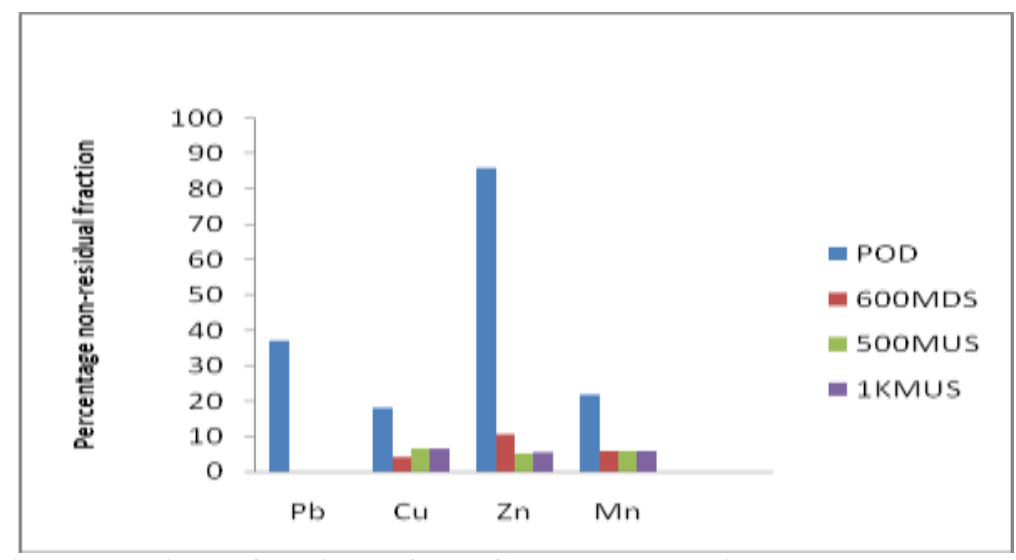

Figure 7: Comparing the residual fractions of $\mathrm{Pb}, \mathrm{Cu}, \mathrm{Zn}$ and $\mathrm{Mn}$ in samples collected at $\mathrm{POD}, 600 \mathrm{MDS}$, 500MUS and1KMUS 
The concentrations of metals in the residual fraction were found to be generally low, almost all the metals were found to find more association with the non residual fractions except for $\mathrm{Zn}$ of POD which has high concentration in the residual fraction.

\section{Conclusion}

The result of this research shows that the effluent is safe for discharge into the river and the water is safe for use by the people of Obajana community. The areas of concern where the metal concentrations seem to be high is obviously as a result of other activities however the company also has its contributions especially at location 5 (500MUS) where the river receives fall-off of raw materials, the mobility factor of $\mathrm{Pb}$ at this point is very high and hence this calls for a concern as $\mathrm{Pb}$ has been classified by the united state environmental protection agencies' (USEPA's) as Group B2 (probable human carcinogen) [17].

\section{Reference}

[1] E.E. Obasohan, J.A.O. Oronsaye, and O.I. Eguavoan, Determination of post-dredging concentrations of selected trace metals in water sediment and fresh water mudfish (Clarias gariepinus) from Ikpoba river in Benin City, Edo state, Nigeria. African journal of biotechnology. 6(4), 2007, 470-477.

[2] A.A. Olajire, and F.E. Imeokparie, A study of the water quality of the Osun river: Metal monitoring and geochemistry. Bull chem. Soc. Ethiop. 14(1), 2000, 1-8.

[3] S.O. Adefemi, and E.E. Awokunmi. Determination of physico-chemical parameters and heavy metals in water samples from Itaogbolu area of Ondo-State, Nigeria. African Journal of environmental Science and Technology. 4(3), 2010, 145-148

[4] F.A. Adekola and O.O.A. Eletta, A study of heavy metal pollution of Asa River, Ilorin. Nigeria; trace metal monitoring and geochemistry. Environ monit. Assess 125 (2007) 157 - 163.

[5] G.O. Olutona, O.G. Aribisala, and E.A. Akintunde, A study of chemical speciation of metals in aquatic

[6] bottom sediment of Aiba reservoir, Iwo, Nigeria. African Journal of Environmental Science and Technol.

[7] 6(8), 2012, 312-321.

[8] P. Jaime, A. Rubio, and X. Castillo, Study of chemical speciation in sediments: An approach to vertical

[9] metal distribution in Rapel reservoir (Chile) J. Chil chem. Soc. 48 (3),2003, 1-12.

[10] E.O. Fagbote, and E.O. Olanipekun, (2010) Speciation of heavy metals in soil of Bitumen deposit impacted area of Western Nigeria; European Journal of scientific research. 47( 2), 2010, $265-277$.

[11] United Nations Agenda 21: program of action for sustainable development. RIO declaration on environment and development statement of forest principles.(1993) New York United Nation p.294.

[12] O. Eletta, Physico-chemical characterization, speciation and interaction studies of some pollutants in Asa-river, Kwara state. Nigeria. Ph.D. thesis submitted to Chemistry department, University of Ilorin. (2005) Pg 79

[13] A. Tessier, P.G.C. Cambell, and M. Bisson, Sequential extraction procedure for the speciation of particulate trace metals, Analytical Chemistry.51, 1979, 844-851.

[14] Federal Environmental Protection Agency (FEPA) (1991) Guidelines and standards for environment notice, Federal republic of Nigeria.

[15] World Health Organization, WHO (1996) Guidelines for drinking water quality: Health criteria and compounds. Information, $2^{\text {nd }}$ edition General 2:271

[16] A.A. Olajire, and E.T. Ayodele, E.T., Contamination of road side soil and grass with heavy metals. Environment international., 23 (1), 1997, 91 - 101.

[17] Inyinbor Adejumoke.,Study of heavy metal pollution of soil and water environment arround a mega cement factory in Nigeria. MSc thesis submitted to Chemistry department, University of Ilorin.(2009).

[18] L.J. Evans, Chemistry of metal retention by soils. Env. Sci. Tech, 23(1989)1046-1056.

[19] M.I. Rico, J.M. Avarez, L.M. Lopez-Valdivia, J. Novillo, and A. Obrado, Manganese and Zinc in acidic agricultural soils from central spain: Distribution and phytoavailability prediction with extraction test. Soil Science 174(2), 2009, $94-104$.

[20] S.B. Choi, and Y.S. Yun, Lead biosorption by waste biomass of Corynebacterium glutamicum generated from lysine fermentation process Biotechnology Letters (26), 2004,331-336. 